\title{
The debate on a loss of biodiversity: can we derive evidence from the monitoring of major plant pests and diseases in major crops?
}

\author{
Doriane Dam $^{1} \cdot$ Marine Pallez-Barthel $^{1} \cdot$ Moussa El Jarroudi $^{2} \cdot$ Michael Eickermann $^{1} \cdot$ Marco Beyer $^{1}$
}

Received: 27 January 2020 / Accepted: 22 June 2020 / Published online: 2 July 2020

(c) Deutsche Phytomedizinische Gesellschaft 2020

\begin{abstract}
The European commission directive EC 128/2009 calls for monitoring pests and pathogens of major crops. The monitoring data may be analysed for trends over time, including tests for a potential loss of biodiversity in the domain of plant pests and pathogens. The monitoring programs carried out in Luxembourg since 2007 provided evidence for an increasing role of yellow rust and a decreasing role of brown rust on winter wheat. Vast inter-annual variability was observed at the level of Fusarium head blight and mildew symptoms on winter wheat as well as at the level of Ceutorhynchus counts in oilseed rape, but no trend towards extinction could be demonstrated. Septoria leaf blotch was present in winter wheat at high levels towards the end of all seasons. The maximum number of Brassicogethes aeneus individuals found per main stem and season on oilseed rape increased slightly but significantly between 2007 and 2017. Substantial evidence for highly dynamic changes in the pest populations was found, but no evidence for the vanishing of the monitored species could be demonstrated.
\end{abstract}

Keywords Brassicogethes aeneus · Cropland · Ceutorhynchus napi · Ceutorhynchus pallidactylus · Erysiphe graminis . Fusarium $\cdot$ Puccinia striiformis $f$. sp. tritici $\cdot$ Puccinia triticina $\cdot$ Zymoseptoria tritici

\section{Introduction}

A claim of a loss of flying insect mass of $76 \%$ over a period of 27 years observed in protected areas in Germany (Hallmann et al. 2017) has triggered a debate about a potentially drastic loss of biodiversity. Many ecosystem services with benefits for agriculture are provided and regulated by insects such as pollination, pest control or soil structure (Noriega et al. 2018). Recently, a worldwide decline of the entomofauna was claimed (Sánchez-Bayo and Wyckhuys 2019), but partly questioned by Simmons et al. (2019) due to methodological and geographical limitations. In grasslands and forests, an arthropod decline was reported (Seibold et al.

Electronic supplementary material The online version of this article (https://doi.org/10.1007/s41348-020-00351-9) contains supplementary material, which is available to authorized users.

Marco Beyer

marco.beyer@list.lu

1 Department "Environmental Research and Innovation", Luxembourg Institute of Science and Technology, Belvaux, Luxembourg

2 Campus Arlon "Environment", University of Liège, Arlon, Belgium
2019). Data from cropland may enhance our understanding on the role of agriculture in this context.

In the case of organisms being harmful for crops, the legislation of the European Union (EC 128 2009, Annex III, point 2) calls for monitoring programmes for warning farmers before pests and diseases reach disastrous levels. Since the primary purpose of the pest and disease monitoring programs is the protection of crops, they are usually carried out in fields where local major crops are grown. In many European countries including Luxembourg (El Jarroudi et al. 2015a), wheat is the most common cereal covering 33\% of the European agricultural surface (Kristoffersen et al. 2020). Oilseed rape is the most important dicotyledonous crop in the region of data acquisition (MAVCP 2016), covering about $3.7 \%$ of the farmland in the EU in 2016 (eurostat 2020). Both crops are important elements in the integrated local crop rotations.

Pests and diseases being responsible for either significant yield losses or causing quality losses that exclude products from high-priced market segments are usually in the focus of the monitoring programmes. Fungal pathogens that inflict significant yield loss in winter wheat and which were described to cause the main fungal diseases in Luxembourg (El Jarroudi et al. 2012) include Zymoseptoria 
tritici (Brennan et al. 2019) with losses ranging from 10 to $30 \%$ (Jørgensen et al. 2014), Puccinia triticina (El Jarroudi et al. 2014a, b; Junk et al. 2016), Puccinia striiformis f. sp. tritici (El Jarroudi et al. 2017a) and Erysiphe graminis (Singh et al. 2016). Fusarium head blight (FHB) is associated with the deposition of mycotoxins in the grain. Batches containing, for instance, more than $1.25 \mathrm{mg}$ of the Fusarium toxin deoxynivalenol per kg grain are excluded from human consumption in the EU, greatly diminishing the value of the crop (Capriotti et al. 2010; Pleadin et al. 2013). Among insect pests, Ceutorhynchus species damage the stems of oilseed rape plants. The two species C. napi and C. pallidactylus can be observed on a routine basis in Luxembourg. The pollen beetle Brassicogethes aeneus mines oilseed rape buds to feed on the pollen they contain, thus causing the abortion of the buds before they can produce pods.

Despite some implementation hurdles of integrated pest management that were outlined in detail by Matyjaszczyk (2019), EU member states have established monitoring programs. The resulting time series on pest and pathogen occurrences from agricultural areas may be analysed for trends over time, including tests for a loss of biodiversity within the range of monitored species. Sometimes, pesticide application trials were integrated into the monitoring programs. In the latter case, the effect of pesticides can be established as well.

It was the purpose of the present study to (1) test if evidence for a loss of species can be obtained from a 12-year monitoring of major plant pests and diseases using the Luxembourgish monitoring as a case study and (2) shed more light on the role of pesticides in that context.

\section{Materials and methods}

\section{Plant health assessment}

Symptoms of fungal plant diseases were monitored in Luxembourg between April and June over the period 2007-2018 at the same 4 locations as previously described by Aslanov et al. (2019). At Burmerange (6.28 El49.52 N), Everlange $(5.95$ El49.78 N) and Reuler (6.04 El50.06 N), observations were made throughout the entire duration of the study, while the fourth location slightly changed in 2014 from Christnach (6.27 El49.79 N, observations available from 2007 to 2013) to Bettendorf (6.19 El49.87 N, observations available from 2014 to 2018). In winter wheat, symptoms caused by Zymoseptoria tritici, Puccinia striiformis f. sp. tritici, Puccinia triticina and Erysiphe graminis on leaves were monitored by visual assessment. Winter wheat cultivar susceptibilities towards the diseases as published by the German Federal Office for Plant Varieties (BSA 2018) did not change significantly within the period of observation (Table 1). Winter wheat cultivars, years, locations, sowing dates and previous crops of the fields, where fungal plant diseases were monitored, can be found in supplementary Table 1. Assessors were trained using the online tools provided by the Julius Kühn-Institut (http://prozentualer-befal 1.julius-kuehn.de/schadbilder.php) until a reproducibility of $\pm 5 \%$ was obtained. Assessments were done between the plant growth stages $\mathrm{BBCH} 30$ and $\mathrm{BBCH} 69$ on 10 main shoots per plot. The minimum number of plots per location and treatment was three; the maximum number of plots was four. Observations were done in randomized fungicide untreated control plots and fungicide-treated plots at each
Table 1 Susceptibility ranks (BSA 2018, rank 1 = resistant, rank $9=$ susceptible) of the winter wheat cultivars monitored between the years 2007 and 2018 at 4 locations in Luxembourg

\begin{tabular}{|c|c|c|c|c|c|}
\hline \multirow[t]{2}{*}{ Year } & \multicolumn{5}{|c|}{ Winter wheat cultivar susceptibility rank (mean \pm standard deviation) } \\
\hline & Septoria & Yellow rust & Brown rust & Mildew & FHB \\
\hline 2007 & $4.75 \pm 0.83$ & $6.00 \pm 2.74$ & $4.75 \pm 1.64$ & $4.75 \pm 2.17$ & $4.00 \pm 0.00$ \\
\hline 2008 & $4.50 \pm 0.87$ & $4.00 \pm 2.83$ & $5.25 \pm 1.92$ & $2.75 \pm 0.83$ & $4.25 \pm 0.43$ \\
\hline 2009 & $4.75 \pm 0.83$ & $3.00 \pm 1.41$ & $6.33 \pm 0.47$ & $3.33 \pm 1.25$ & $4.50 \pm 0.50$ \\
\hline 2010 & $4.75 \pm 0.83$ & $3.75 \pm 1.79$ & $6.50 \pm 0.50$ & $4.00 \pm 1.00$ & $4.00 \pm 0.00$ \\
\hline 2011 & $5.75 \pm 0.43$ & $4.75 \pm 2.68$ & $6.00 \pm 0.82$ & $5.33 \pm 2.05$ & $4.00 \pm 0.00$ \\
\hline 2012 & $5.75 \pm 0.43$ & $4.75 \pm 2.68$ & $6.00 \pm 0.82$ & $5.33 \pm 2.05$ & $4.00 \pm 0.00$ \\
\hline 2013 & $5.33 \pm 0.47$ & $4.67 \pm 2.05$ & $6.00 \pm 0.82$ & $4.33 \pm 0.94$ & $4.00 \pm 0.00$ \\
\hline 2014 & $5.25 \pm 1.09$ & $5.50 \pm 2.29$ & $5.33 \pm 0.47$ & $4.33 \pm 0.94$ & $5.00 \pm 1.00$ \\
\hline 2015 & $5.25 \pm 1.09$ & $5.50 \pm 2.29$ & $5.00 \pm 0.71$ & $4.25 \pm 0.83$ & $5.00 \pm 0.82$ \\
\hline 2016 & $4.67 \pm 0.47$ & $4.67 \pm 2.05$ & $5.00 \pm 0.82$ & $4.67 \pm 0.47$ & $4.50 \pm 0.50$ \\
\hline 2017 & $5.00 \pm 0.00$ & $6.50 \pm 0.87$ & $5.25 \pm 0.43$ & $5.00 \pm 0.00$ & $4.00 \pm 0.00$ \\
\hline 2018 & $4.40 \pm 0.49$ & $4.40 \pm 2.24$ & $4.20 \pm 0.75$ & $4.20 \pm 0.75$ & $4.40 \pm 0.49$ \\
\hline
\end{tabular}

Differences over time were non-significant at $P=0.497, P=0.921, P=0.231, P=0.838, P=0.491$ for Septoria leaf blotch, yellow rust, brown rust, mildew and Fusarium head blight (FHB), respectively (ANOVA). Winter wheat cultivar names are given in supplementary Table 1 
location. A fungicide spray including a triazole and chlorothalonil as active ingredients was applied according to the timing recommended by the model "Proculture" (El Jarroudi et al. 2009). Triazoles were applied at the full rate permitted in the registration, while chlorothalonil was applied at $66 \%$ of the maximum rate allowed. The plot size was $7.5 \times 1.5 \mathrm{~m}$. Winter wheat was sown in October, and previous crops were mostly oilseed rape or maize (supplementary Table 1). Tillage was done according to the local farmer's judgement including minimum tillage without ploughing on some fields and ploughing on other fields. Total nitrogen fertilization ranged from 165 to $228 \mathrm{~kg} \mathrm{~N}$ per ha and was split into two or three application times. The climate in the area monitored has a tendency towards cold and damp and is temperate. The monthly average temperatures and monthly precipitation sums for each year and region are available in supplementary Table 2. Beyond leaf diseases, Fusarium head blight symptoms were monitored annually (except for 2013) in at least 16 commercial wheat fields as previously described by Beyer et al. (2014). In case of Fusarium head blight, fields were treated with fungicides by the farmers according to the local recommendations. In total, 120 wheat heads were sampled for head blight assessments per field.

\section{Insect counts}

The number of Ceutorhynchus napi and C. pallidactylus individuals that were found within 3 days in yellow water traps installed at the corners of commercial winter oilseed rape fields was counted between the plant growth stages BBCH 31 and BBCH 61 each year between 2007 and 2017. Furthermore, the number of Brassicogethes aeneus individuals per main shoot was counted within the same period indicated above. The methods of sampling and counting were described in detail by Eickermann et al. (2015). Briefly, yellow traps (Baumann Saatzucht, Waldenburg, Germany) were installed at a distance of approximately $15 \mathrm{~m}$ from the field margin. Traps were filled with tap water. A droplet of the surfactant 'Ultra' (Cora Belgium S.A./N.V., Belgium) was added for breaking the surface tension of the water. The trap height was adjusted to the top of the canopy every week. Three small holes ( $3 \mathrm{~mm}$ in diameter) were drilled into the middle of the side panels to avoid a loss of sampled insects by overflowing rainwater. No insecticides were applied at the margins of the fields, where the traps were located, while insecticides were applied in the remainders of the fields with respect to the principles of integrated pest management. Briefly, C. napi and C. pallidactylus were controlled by using insecticides from the pyrethroid group, mainly deltamethrin as well as lambda-cyhalothrine. A spray was applied when the control threshold (10 individuals of one species within 3 days per trap) was reached. Since $B$. aeneus showed increasing levels of resistance to the type
II pyrethroids (Eickermann et al. 2011), a resistance management was required in Luxembourg since 2007. Between 2007 to 2010, the type I pyrethroid bifenthrin was used for the first application in April, sometimes followed by a neonicotinoid (thiacloprid) application 10 days later in case the control threshold was reached again. Starting in 2012, pymetrozine was used for the first application in April, followed - if necessary - by a second application of a neonicotinoid. The active ingredient indoxacarb from the group of the oxadiazines was rarely used to control the pollen beetle in Luxembourg. Compared with other regions, the number of insecticide applications in oilseed rape was moderate in Luxembourg (Richardson 2008; Heimbach 2017). Previous crops were mostly winter cereals, and the preferred tillage method was the use of a cultivator and a plough. Locations, cultivars, previous crops, tillage, sowing dates and seed rates are given in supplementary Table 3 for each year of the pest monitoring in oilseed rape. The methods used targeted the sampling of adult insects. Individuals were transferred to ethanol $(70 \%, \mathrm{v} / \mathrm{v})$ and identified under a binocular.

\section{Indicator for presence and absence of a species}

The worst-case scenario in terms of biodiversity is the extinction of species. In this situation, the maximum number of individuals that can be found is zero. Concerning the disease assessments, the percentage of plants showing symptoms on the three upper leaves was determined for each location and each observation date and we used the maximum percentage of symptomatic plants per season as endpoint. Similarly, for insect counts, the endpoint was the maximum number of insects observed per season. Due to pest and disease spread, the percentage of symptomatic or infested plants usually increased within each season, such that the maximum level was mostly observed towards the end of the cropping period (Fig. 1). All statistical analysis were performed using the software package SPSS (version 19, IBM Corporation, Armonk, New York, USA). Trends in the annual maximum level of pests or diseases observed over time covering the period since 2007 were tested by using linear regression. Significance of trends was assumed, if the slope parameter of the regression line differed from zero at $P<0.05$. Cultivar susceptibilities among years were compared using one-way analyses of variance for each disease.

\section{Results}

\section{Winter wheat pathogens}

Septoria leaf blotch caused by Z. tritici was observed in all years in Luxembourg at final levels close to $100 \%$ of infected plants (Fig. 2a, black circles). A fungicide application 


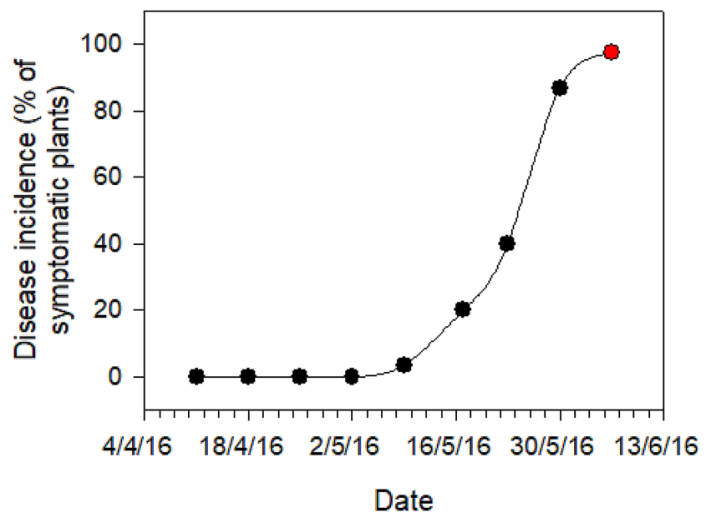

Fig. 1 Time course of the percentage of symptomatic plants (yellow rust) on winter wheat at allocation Bettendorf in cultivar Kerubino in 2016. Plot symbols represent means of four fungicide untreated plots with 10 monitored plants in each plot. If the highest level observed should be $=0$, the species concerned must be considered as absent. The highest level observed (usually towards the end of a cropping season, marked red) of each organism was therefore used as indicator for a potential absence of a species

delayed epidemics but had very little effect on the maximum percentage of symptomatic plants that was observed towards the end of a growing period (Fig. 2a, white circles). Trends over years were non-significant at $P=0.1245$ and $P=0.2063$ for control and fungicide-treated plots, respectively.

Stripe rust caused by $P$. striiformis was increasingly observed since 2012 (Fig. 2b). In the years 2012 and 2013, when maximum percentage of stripe rust in fungicide free plots was around 30 and $65 \%$, a fungicide spray was able to reduce the maximum level of symptomatic plants to almost zero, but afterwards, the maximum stripe rust incidence was hardly affected by the fungicide spray (Fig. 2b). The incidence of stripe rust increased during the period of observation (Fig. 2b). The increase over time was significant at $P=0.0042$ for control plots and non-significant at $P=0.1011$ for fungicide-treated plots.

Brown rust caused by $P$. triticina was observed at levels close to 100\% between 2007 and 2010 (Fig. 2c). From 2012 to 2013, brown rust incidence dropped to about 50\% with huge inter-annual fluctuations (Fig. 2c). Except for the year 2014, the fungicide application decreased brown rust incidence (Fig. 2c). The incidence of brown rust decreased during the period of observation. Maximum brown rust levels decreased from $87.5 \%$ of symptomatic plants in sprayed plots in 2009 to $28.5 \pm 12.6 \%$ of symptomatic plants between 2013 and 2017. The decrease over time was non-significant at $P=0.0971$ for control plots and slightly significant at $P=0.0491$ for fungicide-treated plots.

Mildew caused by Erysiphe graminis was almost absent in the year 2007 and increased to a level of more than $80 \%$ symptomatic plants in 2009 (Fig. 2d). Until 2011, the percentage of symptomatic plants dropped to almost zero, just
Fig. 2 Maximum annual percentage of symptomatic plants infected by a Zymoseptoria tritici, b Puccinia striiformis f. sp. tritici, c Puccinia triticina, d Erysiphe graminis and e Fusarium species that was observed in Luxembourg between the years 2007 and 2018. Whenever points are missing, the respective disease was not found and not recorded quantitatively. Typical symptoms of the diseases are depicted on the right-hand side of the graph

to increase to levels $>70 \%$ in 2013. Between 2014 and 2016, hardly any mildew was observed on winter wheat (Fig. 2d). In 2017 and 2018, levels of about $80 \%$ of symptomatic plants were reached (Fig. 2d). The largest difference of $25 \%$ between control and fungicide-treated plots was observed in the year 2013, when mildew epidemics were most severe. (Fig. 2d). Linear trends over time were non-significant at $P=0.5549$ and at $P=0.9644$ for control and fungicidetreated plots, respectively.

Maximum annual Fusarium head blight symptoms were about $70 \%$ in 2007 and decreased to almost zero until 2011, then increased to about $60 \%$ until 2015 and then declined to about $10 \%$ in 2017 to increase to about $60 \%$ in 2018 , again (Fig. 2d). Fusarium head blight symptoms were characterized by strong fluctuations with no clear trend over time (Fig. 2d, $P=0.4973$ ).

\section{Oilseed rape pests}

The number of $C$. napi adults that was found per yellow trap within 3 days oscillated within 1 and 26 between the years 2007 and 2017 with no consistent trend over time (Fig. 3a, $P=0.4253$ ). The maximum number of $C$. pallidactylus individuals trapped within 3 days averaged 20 except for the year 2012 when up to 256 adults were found after 3 days in one yellow trap (Fig. 3b). There was no significant change over time for $C$. pallidactylus $(P=0.9230)$. The maximum number of $B$. aeneus adults found per main shoot of rapeseed plants was 5 and 4 in 2007 and 2008, respectively; then, it decreased from 8 in 2009 to 3 in 2011 (Fig. 3c). Until 2015, it increased up to 11 and then decreased to 7 in 2016 and increased again to 9 in 2017 (Fig. 3c). On average, the maximum number of $B$. aeneus adults found per main shoot of rapeseed plants increased significantly between 2007 and 2017 ( $P=0.0467$, Fig. 3c).

\section{Discussion}

\section{Winter wheat pathogens}

A strength of the pest and pathogen monitoring data being produced in response to European commission directive EC 128 (2009) is that relatively long time series are available by now, but a limitation is the fact that rare species that 


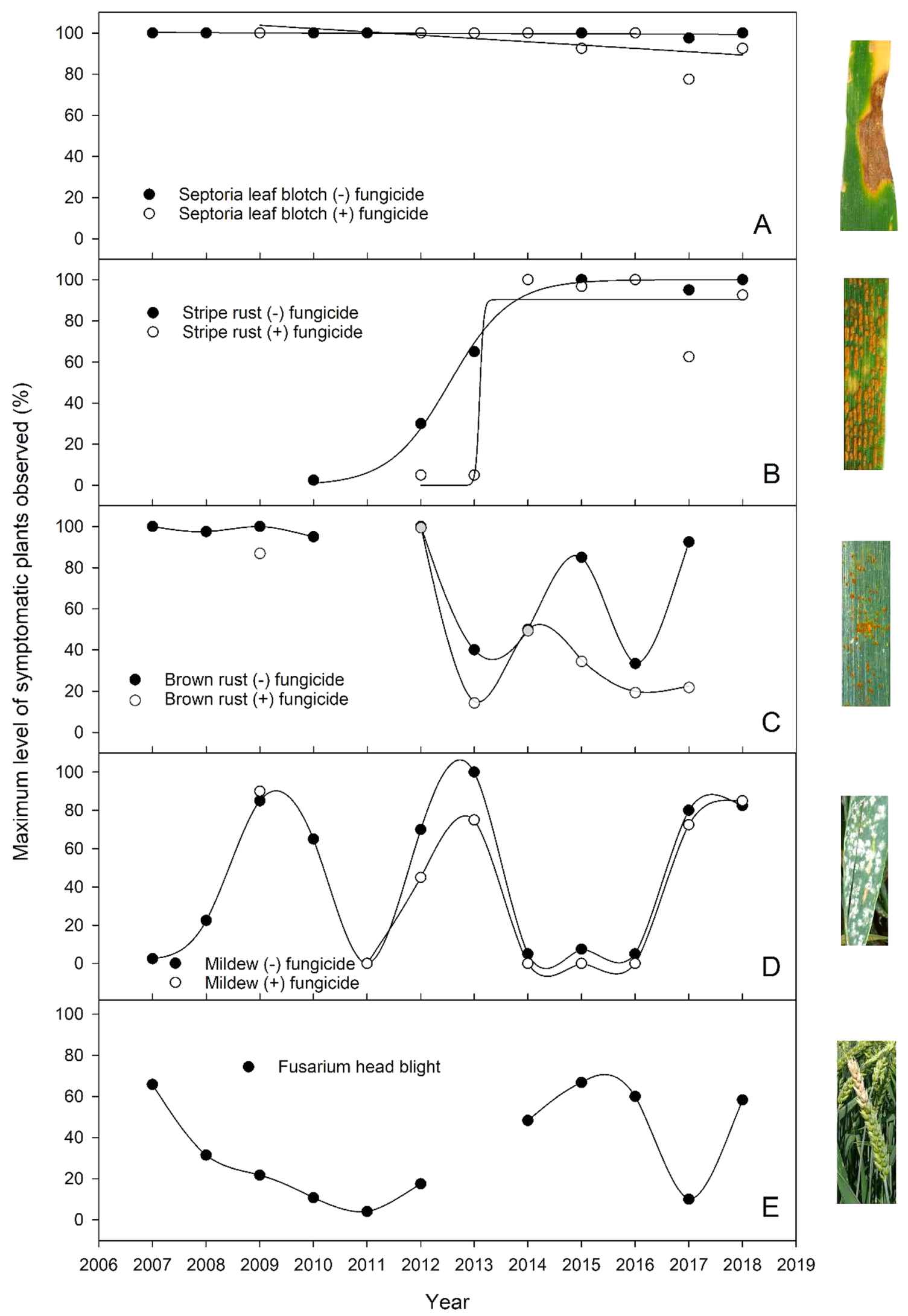




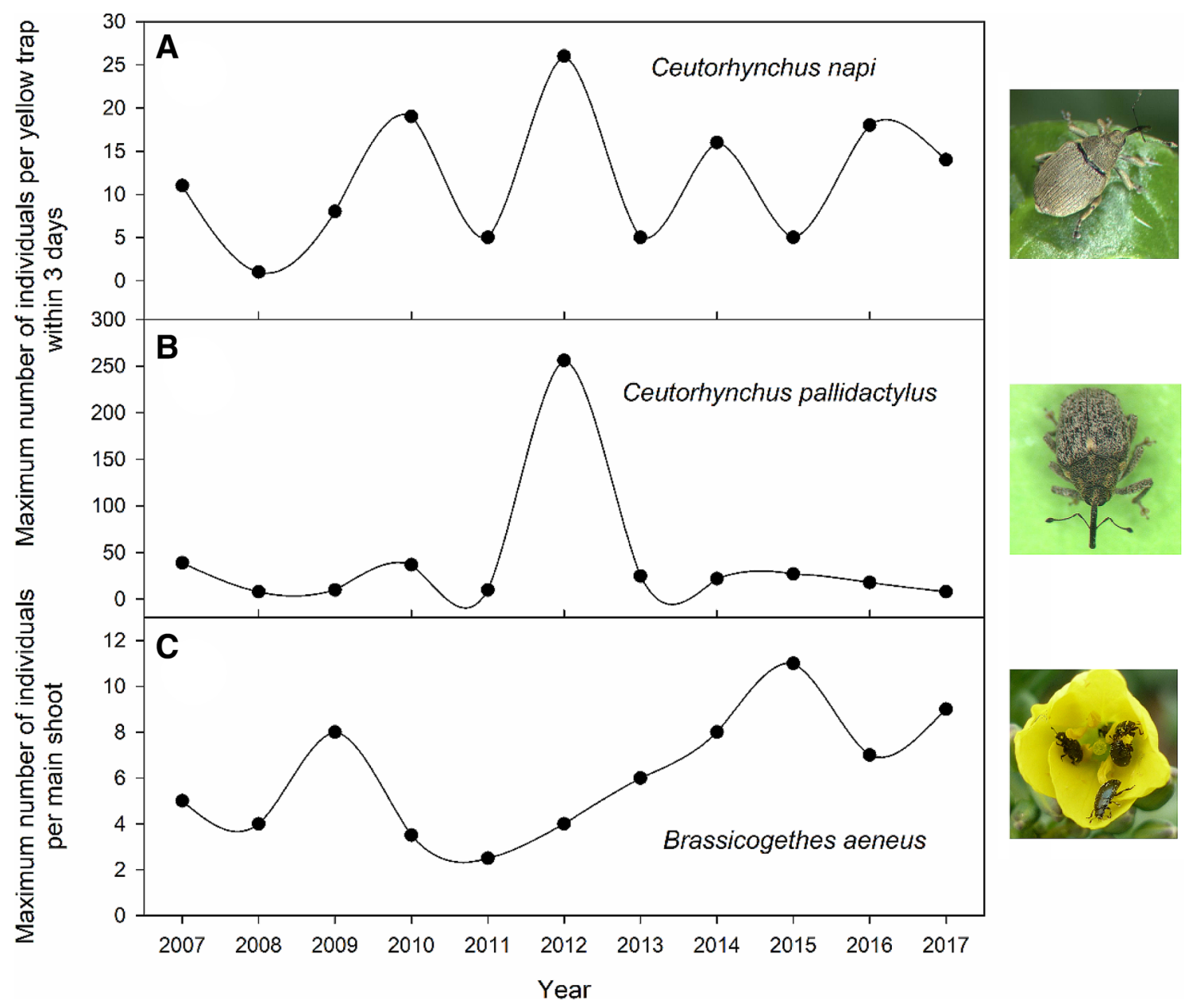

Fig. 3 Maximum annual number of Ceutorhynchus napi a and C. pallidactylus $\mathbf{b}$ individuals that were found per yellow trap within 3 days between February and April between 2009 and 2017 at 5 locations in Luxembourg. Maximum number of Brassicogethes aeneus individuals $\mathbf{c}$ that were found on the main stem of rapeseed plants in spring

did not cause significant economic damage were usually not included.

Septoria leaf blotch was present at high levels on winter wheat towards the end of all seasons. The monitoring of pathogens provided evidence for an increasing role of yellow rust in the winter wheat stands of Luxembourg over the period 2007-2018. de Vallavieille-Pope et al. (2012) studied yellow rust epidemics in France between 1984 and 2009 and observed large inter-annual variability that they explained by the deployment of new resistant cultivars or environmental factors (colder winters, warmer summers or lack of precipitation). In another study, an increase in the frequency and severity of yellow rusts epidemics was observed in Southern and Western Europe between 2001 and 2010 (Morgounov et al. 2012). In our case, the increasing severity of the epidemics depicted in Fig. $2 b$ could well be explained by the introduction of new yellow rust strains between 2009 and 2017 in Luxembourg. Adults of the pest species are depicted on the right-hand side of the graph. The monitored fields were managed according to the integrated farming practices. For details, please see supplementary Table 3

that were able to infect a wider spectrum of wheat cultivars in Europe since 2013 (Hovmøller et al. 2016). During the period 1969-2010 and particularly within the last decade, increases both in the frequency and the severity of brown rust epidemics have been observed in Southern and Western Europe (Morgounov et al. 2012). In Luxembourg, the disease severity was maximum until 2010 and then a negligible decrease has been observed in unsprayed plots. However, a more significant decrease was found in sprayed plots where the maximum brown rust levels decreased from $87.5 \%$ of symptomatic plants in 2009 to $28.5 \pm 12.6 \%$ of symptomatic plants between 2013 and 2017. Large inter-annual variability was observed in the level of FHB in winter wheat, but no trend towards extinction could be demonstrated. Strong fluctuations in the incidence of Fusarium head blight epidemics were previously reported to be related to rain during winter wheat anthesis. In wet years, high incidences were 
observed, while in dry years, hardly any symptoms could be found (Beyer et al. 2014). Since major Fusarium species such as $F$. graminearum and $F$. culmorum are naturally resistant to major fungicides (Dubos et al. 2011; Pasquali et al. 2013), their occurrence may be stronger influenced by environmental factors like weather than by fungicides. Powdery mildew severity in winter wheat was highly variable depending on the year in Luxembourg. According to Morgounov et al. (2012), this foliar disease was one of the most frequently reported diseases in Southern and Western Europe from 1969 to 2010.

Fungicide application can delay leaf blotch epidemics, but it can hardly prevent epidemics under Luxembourgish conditions (Beyer et al. 2012). The period of efficacy of commercial fungicides ranges from 16 to 22 days (Greiner et al. 2019). Therefore, high disease incidence was found also in fungicide-treated plots, even though the high values were usually observed later than in untreated controls (Beyer et al. 2012).

In integrated pest management (IPM), pesticide use is triggered when the density of a pest exceeds the control threshold (Beer 2005), implying that minor pest levels are left uncontrolled. The more pests decline, the less pesticide use is necessary. A decline of plant pests should therefore be associated with a decrease in pesticide use. Extinction of a monitored target species due to pesticides is thus only possible if the principles of IPM are widely ignored, or, if pesticide effects unfold after a significant time lag. Given that the efficacy period of commercial fungicides against Septoria leaf blotch hardly exceeds 22 days (Greiner et al. 2019), the hypothesis of effects that may lead to the extinction of a species after this period seems questionable, at least in case of the causal agent of Septoria leaf blotch and the tested commercial fungicides. No evidence for the extinction of the plant pathogens that were monitored in conventionally managed agricultural fields could be demonstrated here.

\section{Oilseed rape pests}

Large inter-annual variability was observed at the level of Ceutorhynchus counts on rapeseed, but no trend towards extinction could be demonstrated. There was a slightly significant increase for pollen beetle in Luxembourg between 2007 and 2017. Overall, substantial evidence for highly dynamic changes in the pest populations was observed, but no evidence for the vanishing of the monitored species could be demonstrated. The reasons for the absence of a clear decline of the monitored pests is currently unknown, but it may be related to a rather small average field size (1.8 ha per field in Luxembourg, Clermont et al. (2015)) that was shown to be approximately as effective in preserving biodiversity as wildlife-friendly farming practices in Canada (Martin et al. 2020).

\section{A plea for publishing pest and disease monitoring trend data}

Finally, the authors of the present paper wish to encourage colleagues who are involved in the monitoring of pests and diseases to analyse their data for long-term trends and publish the results to enhance our picture of which organisms decline or spread when and where, and, potentially, why.

Acknowledgements We thank Rufat Aslanov, Tiphaine Dubos, Frédéric Giraud, Mélanie Gollier, Friderike Pogoda, Louis Kouadio, Christophe Mackels, Jasmin Mahboubi, Abdeslam Mahtour, Bertrand Martin, Aura Montemayor, Michel Noel, Matias Pasquali, Farid Traoré, Mohammed Sallah Abdoulhamid, Aziz Diouf, Virginie Schyns and Carine Vrancken for excellent technical assistance and the Administration des Services Techniques de 1'Agriculture of Luxembourg for financially supporting the project Sentinelle.

\section{Compliance with ethical standards}

Conflict of interest The authors declare that they have no conflict of interest.

Human and animal rights This article does not contain any studies with human subjects. The treatments of the animals done by the farmers comply with the local animal welfare laws, guidelines and policies.

\section{References}

Aslanov R, El Jarroudi M, Gollier M, Pallez-Barthel M, Beyer M (2019) Yellow rust does not like cold winters. But how to find out which temperature and time frames could be decisive in vivo? J Plant Pathol 101:539-546. https://doi.org/10.1007/s42161-01800233-y

Beer E (2005) Arbeitsergebnisse aus der Projektgruppe „Krankheiten im Getreide"der Deutschen Phytomedizinischen Gesellschaft e. V.. Gesunde Pflanzen 57: 59-70. https://doi.org/10.1007/s1034 3-004-0064-5

Beyer M, El Jarroudi M, Junk J, Pogoda F, Dubos T, Görgen K, Hoffmann L (2012) Spring air temperature accounts for the bimodal temporal distribution of Septoria tritici epidemics in the winter wheat stands of Luxembourg. Crop Protect 42:250-255. https:// doi.org/10.1016/j.cropro.2012.07.015

Beyer M, Pogoda F, Pallez M, Lazic J, Hoffmann L, Pasquali M (2014) Evidence for a reversible drought induced shift in the species composition of mycotoxin producing Fusarium head blight pathogens isolated from symptomatic wheat heads. Int J Food Microbiol 182-183:51-56. https://doi.org/10.1016/j.ijfoodmicr o.2014.05.002

Brennan CJ, Benbow HR, Mullins E, Doohan FM (2019) A review of the known unknowns in the early stages of Septoria tritici blotch disease of wheat. Plant Pathol 68:1427-1438. https://doi. org/10.1111/ppa.13077

BSA (2018) Beschreibende Sortenliste Getreide, Mais, Öl- und Faserpflanzen, Leguminosen, Rüben, Zwischenfrüchte (2018). 
https://www.bundessortenamt.de/bsa/media/Files/BSL/bsl_getre ide_2018.pdf

Capriotti AL, Foglia P, Gubbiotti R, Roccia C, Samperi R, Laganà A (2010) Development and validation of a liquid chromatography/ atmospheric pressure photoionization-tandem mass spectrometric method for the analysis of mycotoxins subjected to commission regulation (EC) No. 1881/2006 in cereals. J Chromatogr A 1217:6044-6051. https://doi.org/10.1016/j.chroma.2010.07.018

Clermont A, Eickermann M, Kraus F, Hoffmann L, Beyer M (2015) Correlations between land covers and honey bee colony losses in a country with industrialized and rural regions. Sci Total Environ 562:1-13. https://doi.org/10.1016/j.scitotenv.2015.05.128

de Vallavieille-Pope C, Ali S, Leconte M, Enjalbert J, Delos M, Rouzet J (2012) Virulence dynamics and regional structuring of Puccinia striiformis f. sp. tritici in France between 1984 and 2009. Plant Dis 96:131-140. https://doi.org/10.1094/PDIS-02-11-0078

Dubos T, Pasquali M, Pogoda F, Hoffmann L, Beyer M (2011) Evidence for natural resistance towards trifloxystrobin in Fusarium graminearum. Eur J Plant Pathol 130:239-248. https://doi. org/10.1007/s10658-011-9749-7

EC 128 (2009) Directive 2009/128/EC of the European Parliament and of the Council of 21 October 2009 establishing a framework for Community action to achieve the sustainable use of pesticides. Official Journal of the European Union. L 309: 71-83. https:// eur-lex.europa.eu/LexUriServ/LexUriServ.do?uri=OJ:L:2009:3 09:0071:0086:en:PDF

Eickermann M, Delfosse P, Hoffmann L, Beyer M (2011) A note on insecticide sensitivity status of Meligethes species (Coleoptera: Nitidulidae) in Luxembourg. J Plant Dis Prot 118:134-140. https ://doi.org/10.1007/BF03356393

Eickermann M, Junk J, Hoffmann L, Beyer M (2015) Forecasting the breaching of the control threshold for Ceutorhynchus pallidactylus in oilseed rape. Agric For Entomol 17:71-76. https://doi. org/10.1111/afe.12082

El Jarroudi M, Delfosse P, Maraite H, Hoffmann L, Tychon B (2009) Assessing the accuracy of simulation model for Septoria leaf blotch disease progress on winter wheat. Plant Dis 93:983-992. https://doi.org/10.1094/PDIS-93-10-0983

El Jarroudi M, Kouadio L, Delfosse P, Giraud F, Junk J, Hoffmann L, Maraite H, Tychon B (2012) Typology of the main fungal diseases affecting winter wheat in the Grand Duchy of Luxembourg. J Agric Sci Technol A 2:1386-1399

El Jarroudi M, Kouadio L, Beyer M, Giraud F, Tychon B, Delfosse P (2013) Factors affecting tan spot on winter wheat in the GrandDuchy of Luxembourg. J Plant Pathol 1:S1.7-S1.17

El Jarroudi M, Kouadio L, Delfosse P, Tychon B (2014a) Brown rust disease control in winter wheat: I. Exploring an approach for disease progression based on night weather conditions. Environ Sci Pollut Res 21:4797-4808. https://doi.org/10.1007/s1135 6-013-2463-6

El Jarroudi M, Kouadio L, Giraud F, Delfosse P, Tychon B (2014b) Brown rust disease control in winter wheat: II. Exploring the optimization of fungicide sprays through a decision support system. Environ Sci Pollut Res 21:4809-4818. https://doi.org/10.1007/ s11356-014-2557-9

El Jarroudi M, Kouadio L, Beyer M, Junk J, Hoffmann L, Tychon B, Maraite H, Bock CH, Delfosse P (2015a) Economics of a decision-support system for managing the main fungal diseases of winter wheat in the Grand-Duchy of Luxembourg. Field Crops Res 172:32-41. https://doi.org/10.1016/j.fcr.2014.11.012

El Jarroudi M, Kouadio L, Junk J, Beyer M, Pasquali M, Bock CH, Delfosse P (2015b) Do single, double or triple fungicide sprays differentially affect the grain quality in winter wheat? Field Crops Res 183:257-266. https://doi.org/10.1016/j.fcr.2015.08.012

El Jarroudi M, Kouadio L, Bock CH, El Jarroudi M, Junk J, Pasquali M, Maraite H, Delfosse P (2017a) A threshold-based weather model for predicting stripe rust infection in winter wheat. Plant Dis 101:693-703. https://doi.org/10.1094/PDIS-12-16-1766-RE

El Jarroudi M, Kouadio L, El Jarroudi M, Junk J, Bock C, Diouf AA, Delfosse $\mathrm{P}$ (2017b) Improving fungal disease forecasts in winter wheat: a critical role of intra-day variations of meteorological conditions in the development of Septoria leaf blotch. Field Crops Res 213:12-20. https://doi.org/10.1016/j.fcr.2017.07.012

Eurostat (2020): https://ec.europa.eu/eurostat/statistics-explained/index .php/Farms_and_farmland_in_the_European_Union_-_statistics Accessed 12/06/2020

Giraud F, Pasquali M, El Jarroudi M, Vrancken C, Brochot C, Cocco E, Hoffmann L, Delfosse P, Bohn T (2010) Fusarium head blight and associated mycotoxin occurrence on winter wheat in Luxembourg in 2007/2008. Food Addit Contam 27:825-835. https://doi. org/10.1080/19440040903567232

Greiner SD, Racca P, Jung J, von Tiedemann A (2019) Determining and modelling the effective period of fungicides against septoria leaf blotch in winter wheat. Crop Prot 117:45-51. https://doi. org/10.1016/j.cropro.2018.11.004

Hallmann CA, Sorg M, Jongejans E, Siepel H, Hofland N, Schwan H, Stenmans W, Müller A, Sumser H, Hörren T, Goulson D, de Kroon H (2017) More than 75 percent decline over 27 years in total flying insect biomass in protected areas. PLoS ONE 12:e0185809. https://doi.org/10.1371/journal.pone.0185809

Heimbach U (2017) Summary of findings from a participant country questionnaire on pest insects in oilseed rape. In: Proceedings, EPPO workshop on integrated management of insect pests in oilseed rape. 20.-22. September 2017, Berlin

Hovmøller MS, Walter S, Bayles RA, Hubbard A, Flath K, Sommerfeldt N, Leconte M, Czembor P, Rodriguez-Algaba J, Thach T, Hansen JG, Lassen P, Justesen AF, Ali S, de VallavieillePope C (2016) Replacement of the European wheat yellow rust population by new races from the Centre of diversity in the near-Himalayan region. Plant Pathol 65:402-411. https://doi. org/10.1111/ppa.12433

Jørgensen LN, Hovmøller MS, Hansen JG, Lassen P, Clark B, Bayles R, Rodemann B, Flath B, Jahn M, Goral T, Czembor JC, Cheyron P, Maumene C, De Pope C, Ban R, Nielsen GC, Berg $G$ (2014) IPM strategies and their dilemmas including an introduction to www. Eurowheat.Org. J Integr Agric 13:265-281. https://doi.org/10.1016/S2095-3119(13)60646-2

Junk J, Kouadio L, Delfosse P, El Jarroudi M (2016) Effects of regional climate change on brown rust disease in winter wheat. Clim Change 135:439-451. https://doi.org/10.1007/s1058 4-015-1587-8

Kristoffersen R, Jørgensen LN, Eriksen LB, Nielsen GC, Pødenphant Kiær L (2020) Control of Septoria tritici blotch by winter wheat cultivar mixtures: meta-analysis of 19 years of cultivar trials. Field Crops Res 249:107696. https://doi.org/10.1016/j.fcr.2019.107696

Martin AE, Collins SJ, Crowe S, Girard J, Naujokaitis-Lewis I, Smith AC, Lindsay K, Mitchell S, Fahrig L (2020) Effects of farmland heterogeneity on biodiversity are similar to-or even larger thanthe effects of farming practices. Agr Ecosyst Environ 288:106698. https://doi.org/10.1016/j.agee.2019.106698

Matyjaszczyk E (2019) Problems of implementing compulsory integrated pest management. Pest Manag Sci 75:2063-2067. https:// doi.org/10.1002/ps.5357

MAVCP (2016) Luxembourgish agriculture, facts and figures. Ministry of agriculture, viticulture and consumer protection. Available at https://agriculture.public.lu/dam-assets/publications/ser/stati stiques/landwirtschaft-in-zahlen/the-agriculture-of-luxembourg -2016.pdf

Morgounov A, Tufan HA, Sharma R, Akin B, Bagci A, Braun HJ, Kaya Y, Keser M, Payne TS, Sonder K, McIntosh R (2012) Global incidence of wheat rusts and powdery mildew during 1969-2010 and durability of resistance of winter wheat variety Bezostaya 1 . 
Eur J Plant Pathol 132:323-340. https://doi.org/10.1007/s1065 8-011-9879-y

Noriega JA, Hortala J, Azcáratec FM, Bergd MP, Bonadaf N, Brionesg MJI, Del Toroh I, Goulsoni D, Ibanezj S, Landisk DA, Morettil M, Potts SG, Sladen EM, Stout JC, Ulyshen MD, Wackers FL, Woodcock BA, Santos AMC (2018) Research trends in ecosystem services provided by insects. Basic Appl Ecol 26:8-23. https://doi. org/10.1016/j.baae.2017.09.006

Pasquali M, Spanu F, Scherm B, Balmas V, Hoffmann L, HammondKosack KE, Beyer M, Migheli Q (2013) FcStuA from Fusarium culmorum controls wheat foot and root rot in a toxin dispensable manner. PLoS ONE 8:e57429. https://doi.org/10.1371/journ al.pone.0057429

Pleadin J, Vahčić N, Perši N, Ševelj D, Markov K, Frece J (2013) Fusarium mycotoxins' occurrence in cereals harvested from Croatian fields. Food Control 32:49-54. https://doi.org/10.1016/j.foodc ont.2012.12.002

Richardson DM (2008) Summary of findings from a participant country pollen beetle questionnaire. EPPO Bulletin 38:68-72. https:// doi.org/10.1111/j.1365-2338.2008.01183.x

Sánchez-Bayo F, Wyckhuys KAG (2019) Worldwide decline of the entomofauna: a review of its drivers. Biol Cons 232:8-27. https ://doi.org/10.1016/j.biocon.2019.01.020
Seibold S, Gossner MM, Simons NK, Blüthgen N, Müller J, Ambarlı D, Ammer C, Bauhus J, Fischer M, Habel JC, Linsenmair KE, Nauss T, Penone C, Prati D, Schall P, Schulze E-D, Vogt J, Wöllauer S, Weisser WW (2019) Arthropod decline in grasslands and forests is associated with landscape-level drivers. Nature 574:671674. https://doi.org/10.1038/s41586-019-1684-3

Simmons BI, Balmford A, Bladon AJ, Christie AP, De Palma A, Dicks LV, Gallego-Zamorano J, Johnston A, Martin PA, Purvis A, Rocha R, Wauchope HS, Wordley CFR, Worthington TA, Finch T (2019) Worldwide insect declines: an important message, but interpret with caution. Ecol Evol 9:3678-3680. https://doi.org/10.1002/ ece 3.5153

Singh RP, Singh PK, Rutowski J, Hodson DP, He X, Jørgensen LN, Hovmøller MS, Huerta-Espino J (2016) Disease impact on wheat yield potential and prospects of genetic control. Annu Rev Phytopathol 54:303-322. https://doi.org/10.1146/annurev-phyto-08061 5-095835

Publisher's Note Springer Nature remains neutral with regard to jurisdictional claims in published maps and institutional affiliations. 